\title{
Effects of Emotions and Ethics on Pro-Environmental Behavior of University Employees: A Model Based on the Theory of Planned Behavior
}

\author{
Faiq Aziz *, Ahmad Aizuddin Md Rami, Zeinab Zaremohzzabieh and Seyedali Ahrari \\ Faculty of Educational Studies, Universiti Putra Malaysia, Serdang 43400, Malaysia; \\ ahmadaizuddin@upm.edu.my (A.A.M.R.); z_zienab@upm.edu.my (Z.Z.); seyedaliahrari@upm.edu.my (S.A.) \\ * Correspondence: mohdfaiq@upm.edu.my
}

Citation: Aziz, F.; Md Rami, A.A.; Zaremohzzabieh, Z.; Ahrari, S. Effects of Emotions and Ethics on Pro-Environmental Behavior of University Employees: A Model Based on the Theory of Planned Behavior. Sustainability 2021, 13, 7062. https://doi.org/10.3390/su13137062

Academic Editor: Fanli Jia

Received: 10 May 2021

Accepted: 21 June 2021

Published: 23 June 2021

Publisher's Note: MDPI stays neutral with regard to jurisdictional claims in published maps and institutional affiliations.

Copyright: (c) 2021 by the authors. Licensee MDPI, Basel, Switzerland. This article is an open access article distributed under the terms and conditions of the Creative Commons Attribution (CC BY) license (https:/ / creativecommons.org/licenses/by/ $4.0 /)$.

\begin{abstract}
Over the last few years, many activities conducted by university employees have contributed greatly to the global rise of greenhouse gases responsible for the warming of the planet. This phenomenon can be attributed primarily to altering lifestyle, consumption, and portability patterns. Even though there is a significant applicability, understanding the factors determining the pro-environmental behavior (PEB) of university employees is lacking. Thus, this study extended the theory of planned behavior (TPB) to explain PEB among university employees. Ten hypotheses were suggested regarding the relations between the initial TPB constructs, environmental ethics, and emotional intelligence. A self-reported questionnaire was used to collect data from a randomly selected sample of 302 university employees from six Malaysian higher educational institutions listed in the UI Green Matrix 2016. The findings revealed that environmental ethics significantly affected attitudes, perceived behavioral control, and subjective norms. Furthermore, pro-environmental behavioral intentions (PEIs) were directly influenced by attitude and perceived behavioral control, while emotional intelligence mediated the relationship between PEIs and PEB. Moving forward, this study will provide new insights into the literature of university employees' PEB using an expanded TPB model.
\end{abstract}

Keywords: attitude; intention; environmental ethics; pro-environmental behavior; theory of planned behavior

\section{Introduction}

Universities have over time been the source of social and political change and the institutions of learning. They not only produce most of the world's authorities and educators, but also expand the limits of knowledge. Apart from that, universities are also notable employers and consumers of products and services, significantly positioning themselves in national and global economic roles. Given the ascribed roles of universities in transforming society and the current environmental and sustainability problems, universities are increasingly being pressured to deal with and adapt to climate change and other issues of sustainable development, as well as the threats and opportunities that come with them. Hence, one of the ways to curtail universities' negative impacts on the environment is by understanding the pro-environmental behavior (PEB) of their employees.

In essence, PEB signifies the work ethics wilfully showcased by workers at any organizational level and aimed to conserve or better the natural environment and to make the planet a more hospitable environment for future generations. This can be accomplished by drastically reducing resource use, conserving resources, avoiding waste generation, recycling, and conserving water [1]. For the most part, important eco-friendly behaviors usually not mentioned in job descriptions, such as corporate environmental citizenship behavior, frame the environmental sustainability of an organization; however, more often than not, this is not officially in the jurisdiction of the environmental management system [2]. Of late, PEB has garnered attention for its pivotal role in both organizations and the 
environment [3]. Hence, researchers are studying the efficacy of engaging in environmental volunteering on employees' PEB [4-6].

Despite its importance, PEB is still a new concept for higher education. Thus, understanding factors that influence the university employees' propensity to engage in PEB is key to the environmental sustainability of universities. Several studies [7] have used the theory of planned behavior (TPB) to provide a framework for understanding employees' PEBs. According to TPB [7], attitude (ATT), social norms (SNs), and perceived behavior control (PBC) are antecedents of intention-behavior that will predict the actual behavior $[8,9]$. Meanwhile, several researchers have agreed that the ability of the TPB construct to predict the behavior of a person is more significant when it anticipates the element of nature within the investigation, along with emotional factors and ethical concerns related to the environment [10]. In many studies, emotional intelligence (EI) [11] and environment ethics (EE) [12] have been found to minimize the attitude-behavior gap. Additionally, a review of the environment behavior literature acknowledges that many authors link EI and EE to PEB, suggesting that emotions and ethics may be integral to the PEB of the university employees.

EI is a major component in the formulation of intentions in the sense of environmental behavior, and its role is imperative in environmental decision-making [11-14]. This is because employees who can regulate their emotions can influence their intention to perform the intended behavior or do the opposite, which is not to perform the behavior. According to Mohiyeddini et al. [15], the mediation role of emotion emphasizes the function of intention as the key predictor of behavior, increasing and enhancing the predictability of the TPB model. Additionally, Arvola et al. [16] stated that one significant criticism of the TPB model has been the lack of inclusion of moral or ethical concerns. Thus, it is imperative to provide university employees with both EE and EI so that they become psychologically empowered, and their attitude and beliefs toward PEB change, ultimately prompting universities toward environmental sustainability. Therefore, this study used an expanded TPB model, which included the constructs of EE and EI, to predict the PEB of university employees. The study's specific objectives are as follows: (1) to examine the effects of EE on ATT, SN, and PBC; (2) to examine the influence of ATT, SNs, and PBC on pro-environmental behavior intentions (PEBIs) of university employees; and (3) to examine the mediating role of EI on the relationship between PEB and PEBI.

\section{Literature Review}

\subsection{Theory of Planned Behavior}

Many who have conducted similar studies on PEB have justified that PEB is mainly steered by self-interest and the rational evaluation of behavioral consequences, using TPB to frame its premise $[15,17,18]$. At the outset, TPB was initiated to extend the theory of reasoned action (TRA), and it could only account for voluntary and under-control behaviors. In its original form, TRA predicts a person's behavior where a person's intention to display a specific behavior is driven by his or her attitude towards the behavior and subjective norm $[7,19]$. In essence, ATT signifies a person's positive (favorable) or negative (unfavorable) evaluations of those displaying the behavior, while SNs are the individual's perception of social pressure when displaying a certain mannerism [1]. Ajzen [7] remarked that a person's displayed behavior is heavily dependent upon his or her volitional control. It refers to the person's ability to show how much people are willing to immerse themselves while performing the behavior under the control of power within their beliefs. Hence, TPB is expanded to TRA to address this volitional limitation [19]. TPB argues that an individual's focus to perform a behavior is curtailed by PBC, ARR, and SNs, which hold a useful conceptual framing to guess and justify human behavior [7].

TPB has been widely adopted in the field of environmental studies to predict human behavior $[11,18]$. However, several researchers have pointed out its limitations in explaining individuals' behavioral intentions and actual behaviors [20]. As a result, by broadening the theory, the use of additional variables may improve the predictive power to 
explain PEBI [21,22]. Many researchers have used PEB and added variables such as "moral norm" [23], "past behavior" [24], "self-identity" [25], "habit" [26], "self-efficacy" [27], "environmental awareness" [28], "sense of community" [29], and "environmental values"[30].

EE and EI are two critical factors to predict, understand, and change PEB [31,32]. Evidence has shown that both EE and EI play a significant role in motivating PEB and a strong relation between EI and ethics in predicting PEB [33]. Therefore, TPB constructs such as ATT, SNs, and PBC associated with EI and EE could explain the integrated and comprehensive voluntary PEBI. To predict PEB, this study included the additional variables of EE and EI.

\subsection{Emotional Intelligence (EI)}

EI can foresee many pro-social behaviors amongst its staff $[13,33,34]$; therefore, it might implicate the progress of PEBs. It was initially described as "the ability to track one's own and others' emotions and feelings, to distinguish between them, and to use this knowledge to lead one's thinking and actions" [35] and was eventually summarized to emphasize the perception, usage, understanding, and management of emotions [36].

Empirical studies have shown that EI can positively enhance engagement in PEB [37]. Additionally, other studies have reported direct and indirect effects on PEB. Landa et al. [38] stated that people with EI could easily adapt to their environment, while people who had lower EI levels were not able to adapt easily and their answers might negatively impact their lives. In this regard, we conclude that PEB is influenced not only by cognitive factors, but also by human emotivity.

\subsection{Environmental Ethics}

EE is efficient in affecting behavior changes [39]. Ethics can be described as the art and discipline of applying concepts and structures to analyze and address complex moral issues [40]. Treviño et al. [41] asserted that ethics is the moral principles that guide what is right or wrong, positive or negative, and suitable or unsuitable in different settings. A person who possesses the correct ethical skills and who pays attention to environmental ethics is considered to be part of the strategy to improve the human standard of living [42]. Furthermore, Kibert et al. [43] stated that EE encompassed the conceptual basis of environmental values as well as more pressing issues framing social perceptions, practices, and policies that protected and sustained biodiversity and ecosystems. Abedi Sarvestani and Shah Vali [44] declared that EE implied that inhabitants of the earth were servers of nature and tasked with the responsibility to protect it.

In previous research, TPB was extended through ethical dimensions $[45,46]$. Researchers have concluded that mixing the present theories is better and that mixing moral norms and TPB is the best way to explain PEB [40]. Harland et al. [47] discovered that by including ethics, the proportion of explained variance in intention rose.

\subsection{Hypotheses Testing}

Few studies have investigated the causal relationship between EE and ATT, PBC, and $\mathrm{SN}$ in the context of PEB. Yoon [48] supported the roles of moral obligation and justice derived from ethics theories as predictors of the behavioral intentions of individuals to commit digital piracy even when ATT, SNs, and PBC have been taken into account. In the extended TPB model, Conner and Armitage [49] discovered that moral norms explained an additional $4 \%$ of the variation in intentions after controlling for TPB constructs. Chang and Chou [50] reported that the ethics perspective and three constructs of TPB explained consumers' intention to "Bring Your Shopping Bags" when doing grocery shopping in Taiwan. Dowd and Burke [51] demonstrated that having a good moral attitude increased the TPB's explanatory power dramatically.

Moreover, each of the three TPB constructs is influenced by ethical and moral considerations separately. Ethics was discovered to be linked to ATT constructively [52-55]. Honkanen et al. [46] showed that ethical values based on environmental and animal pro- 
tection explained ATT. Sun et al. [56] reported that ethical belief significantly affected consumers' ATT and intention to use plastic bags in China. On the other hand, Schwartz [57] proposed the norm activation theory, which argued that ethical and moral behavior was the consequence of a personal norm to behave in a certain manner. The moral norm is activated when individuals are aware of the repercussions of their decisions and able to accept responsibility for them. A normative ethical standard may serve as a foundation to shape personal normative beliefs.

In addition to that, Guido et al. [58] illustrated that moral norms or personal beliefs could be considered the main motivator of the purchasing intention of organic food products, and they were, in turn, affected by sns and product personality traits of naturalness and authenticity. Lastly, Park and Ha [59] revealed that personal norms (from the norm activation model) together with PBC influenced the U.S. consumers' intention to recycle. As a result, the proposed analysis aimed to bridge the gap by combining ethics with all three TPB variables to predict PBI. Based on the findings presented above, this study suggests the following hypotheses:

Hypothesis 1 (H1). EE positively affects university employees' ATT toward voluntary PEB.

Hypothesis 2 (H2). EE positively affects university employees' SNs.

Hypothesis 3 (H3). EE positively affects university employees' PBC.

Many empirical studies have found links between the three TPB constructs and PEI [60-62]. According to Ajzen [63], ATT, SNs, and PBC are predictors of behavioral intention. Lin et al. [64] demonstrated that while SNs and PBC affected citizens' behavior intentions towards pro-environmental programs in Indonesia, ATT significantly impacted the citizen behavioral intention. Effendi et al. [65] revealed that the PEI of Indonesian students was influenced by SNs, PBC, and ATT. Mufidah et al. [66] also reported that ATT was the strongest predictor and SNs were the weakest predictor that fundamentally affected the consumers' behavior intention in Taiwan and Indonesia. Based on the previous findings, this study contends that ATT, SNs, and PBC significantly influence the PEI of university employees:

Hypothesis 4 (H4). ATT positively affects university employees' PEI.

Hypothesis 5 (H5). SNs positively affect university employees' PEI.

Hypothesis 6 (H6). PBC positively affects university employees' $P E I$.

Masud et al. [60] demonstrated the mediating effects of the behavioral intention between ATT, SNs, PBC, and PEB of Malaysian people. Atess [61] examined the factors influencing the PEB of 340 science teachers in Turkey using TPB and the value identity personal norm model. The results illustrated that ATT and PBC indirectly influenced PEB, while the indirect relationship between SN and PEB was insignificant. In India, Taufique and Vaithianathan [62] also used behavioral intention as a mediator to investigate the determinants of ecologically conscious consumer behavior among young urban consumers. The results suggested that ATT had a significant indirect positive influence on ecologically conscious consumer behavior. Based on previous empirical studies, the following three hypotheses are proposed in this study:

Hypothesis 7 (H7). University employees' PEI positively mediates the relationship between ATT and PEB.

Hypothesis 8 (H8). University employees' PEI positively mediates the relationship between SN and PEB. 
Hypothesis 9 (H9). University employees' PEI positively mediates the relationship between PBC and PEB.

EI has been considered a predictor of PEB [67-70]. Numerous studies introduced EI as a mediator for actual behavior across different contexts and pointed out that EI mediated the relationship between emotional stability and optimism [71,72]. Guil et al. [72] used EI as a mediator of the relationship between self-esteem and anxiety among university students. Furthermore, Di Fabio et al. [71] demonstrated that EI mediated the relationship between personality traits and both hope and optimism. However, empirical studies on how EI impacts university employees' PEB are lacking. As a result, the proposed framework aims to demonstrate that EI directly affects PEI, and consequently, indirectly affects PEB.

Hypothesis 10 (H10). EI positively mediates the relationship between PEI and university employees' $P E B$.

Figure 1 illustrates a proposed study model focused on the aforementioned hypotheses.

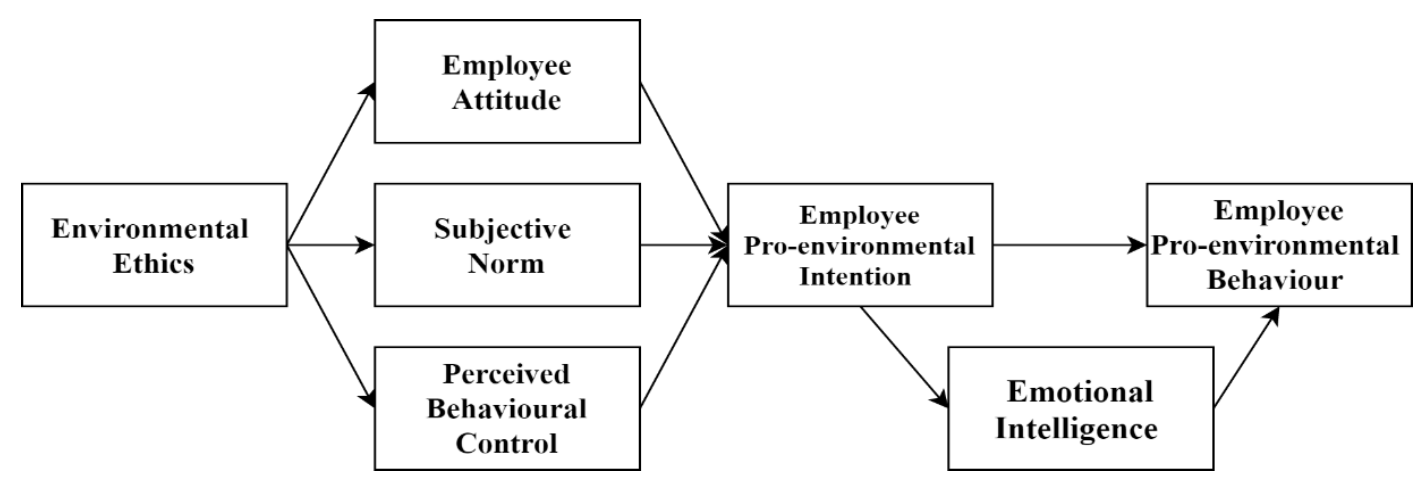

Figure 1. The proposed research model.

\section{Materials and Methods}

\subsection{Measurements}

The self-administered questionnaire was comprised of PEB [30,73], PEBI [74], ATT, PBC, SNs [7,74-76], EE [77-79], and EI [80], and it was split into five parts. The first section was based on the PEB of university employees, containing seven items, including conserving, avoiding harm, transforming, influencing others through behaviors that motivated green behavior, and taking initiatives. The second section was related to PBEI, with five items that included sample items such as, "I plan to purchase eco-friendly office supplies". The third section was related to EE, with ten items that included sample items such as "my university has specific environmental policies in place". The fourth section focused on EI, containing 16 items, including self-emotional appraisal, emotional appraisal, and use of emotions. The fourth section consisted of the TPB constructs, including five items on ATT toward PEB, five items on SNs, and four items on PBC. All items were measured on a 5-point Likert scale ranging from 1 (strongly disagree) to 5 (strongly agree). The last section focused on the background of the employees.

The measurement items were created specifically for this study's context. Two researchers were asked to review the content validity of these items to determine if they were appropriate to evaluate the voluntary PEI of university staff. Additionally, a pilot study was carried out among Malaysian university employees. A few changes were made to the questionnaire's terminology and composition as a result of the two procedures. The questionnaire was first created in English and then translated into Malay (Bahasa Melayu) by two bilingual scholars, taking into account the degree of language heterogeneity among respondents. Then, back-translations into English were performed by two 
separate Malay-English bilingual scholars to ensure the consistency and accuracy of the translations.

\subsection{Data Collection}

We selected six universities at random based on their success in championing the environment and sustainability on a local and international level, as well as their inclusion in the UI Green Matrix 2016 [81,82]. The six selected universities were Universiti Putra Malaysia, Universiti Utara Malaysia, University Malaya, Universiti Teknologi Malaysia, Universiti Kebangsaan Malaysia, and Universiti Tunku Abdul Rahman. In addition to that, employees who had served at one of the six universities for at least a year made up the target population. Fifty-four items were utilized and all factors (i.e., PEB (7 items), EPEI (5 items), ATT ( 7 items), SN (5 items), PBC (4 items), EE (10 items), and EI (16 items)) are displayed in Table 1 . The sample size of 378 met the requirements to use structural equation modeling (SEM), as the ratio of sample size to estimated parameters should be at least 7:1 [83]. According to Hair et al. [81], the preferred minimum number of indicators is three. However, in most cases, five to seven indicators are commonly used to represent a construct.

Data collection took place during November and December 2018. A total of 378 questionnaires were distributed using a stratified random sampling technique at these six universities located in Malaysia. Of those, 76 incomplete questionnaires were eliminated, resulting in a final sample of 302 and yielding a valid response rate of $79.89 \%$. Descriptive statistics was used to describe the demographics of the respondents. Partial least squares structural equation modeling (PLS-SEM) was used to approximate the model fit and evaluate the proposed hypotheses and was chosen because Hair et al. [81] advocated for its suitability to test models ranging from simple to complex as well as small to medium sample sizes. 
Table 1. Construct reliability and validity.

\begin{tabular}{|c|c|c|c|c|c|c|c|c|c|c|c|}
\hline Constructs & Loadings & $\alpha$ & rho_A & CR & AVE & Constructs & Loadings & $\alpha$ & rho_A & CR & AVE \\
\hline $\mathrm{EE}$ & & 0.946 & 0.987 & 0.953 & 0.608 & $\begin{array}{l}\text { 1. I intend to reduce the amount of } \\
\text { paper I use during my daily work } \\
\text { activities. }\end{array}$ & 0.708 & & & & \\
\hline $\begin{array}{l}\text { 1. My university has specific } \\
\text { environmental policies in place. }\end{array}$ & 0.807 & & & & & $\begin{array}{l}\text { 2. I intend to reduce energy usage in } \\
\text { the workplace. }\end{array}$ & 0.856 & & & & \\
\hline $\begin{array}{l}\text { 2. My university has set aside funds } \\
\text { for environmental protection. }\end{array}$ & 0.754 & & & & & $\begin{array}{l}\text { 3. I intend to avoid using plastic } \\
\text { during my daily work activities. }\end{array}$ & 0.755 & & & & \\
\hline $\begin{array}{l}\text { 3. My university integrates } \\
\text { environmental programs, strategies, or } \\
\text { objectives into its culture. }\end{array}$ & 0.803 & & & & & $\begin{array}{l}\text { 4. I intend to purchase office supplies } \\
\text { that are not harmful to the } \\
\text { environment. }\end{array}$ & 0.856 & & & & \\
\hline $\begin{array}{l}\text { 4. All living things have a moral right } \\
\text { to exist. }\end{array}$ & 0.734 & & & & & 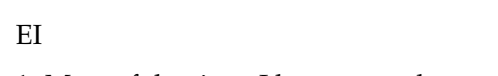 & & 0.847 & 0.856 & 0.898 & 0.688 \\
\hline $\begin{array}{l}\text { 5. The balance of nature is fragile and } \\
\text { can easily be destroyed. }\end{array}$ & 0.780 & & & & & $\begin{array}{l}\text { 1. Most of the time, I have a good } \\
\text { sense of why I have certain feelings. }\end{array}$ & 0.892 & & & & \\
\hline $\begin{array}{l}\text { 6. The earth is like a spaceship with } \\
\text { very limited space and resources. }\end{array}$ & 0.797 & & & & & $\begin{array}{l}\text { 2. I have a good understanding of my } \\
\text { own emotions. }\end{array}$ & 0.871 & & & & \\
\hline $\begin{array}{l}\text { 7. Nature is valuable for its own sake, } \\
\text { even if humans acquire no goods or } \\
\text { services from it. }\end{array}$ & 0.764 & & & & & 3. I completely understand how I feel. & 0.761 & & & & \\
\hline $\begin{array}{l}\text { 8. Breaking the laws of nature will } \\
\text { eventually lead to catastrophe. }\end{array}$ & 0.807 & & & & & $\begin{array}{l}\text { 4. I am always aware of whether I am } \\
\text { happy or not. }\end{array}$ & 0.787 & & & & \\
\hline $\begin{array}{l}\text { 10. Human ingenuity ensures that we } \\
\text { do not make the earth unlivable. }\end{array}$ & 0.806 & & & & & $\begin{array}{l}\text { 6. I am an excellent observer of other } \\
\text { people's emotions. }\end{array}$ & 0.877 & & & & \\
\hline AT & & 0.860 & 0.878 & 0.898 & 0.629 & $\begin{array}{l}\text { 7. I am sensitive to the feelings and } \\
\text { emotions of others. }\end{array}$ & 0.801 & & & & \\
\hline $\begin{array}{l}\text { 1. It important to keep the } \\
\text { environment clean with green office } \\
\text { supplies. }\end{array}$ & 0.719 & & & & & $\begin{array}{l}\text { 8. I have a good understanding of the } \\
\text { emotions of the people around me. }\end{array}$ & 0.822 & & & & \\
\hline $\begin{array}{l}\text { 2. It is important to prevent pollution } \\
\text { in the workplace. }\end{array}$ & 0.836 & & & & & $\begin{array}{l}\text { 9. I always set goals for myself and } \\
\text { then work hard to accomplish them. }\end{array}$ & 0.827 & & & & \\
\hline $\begin{array}{l}\text { 3. It is important to conserve natural } \\
\text { resources in the workplace. }\end{array}$ & 0.815 & & & & & $\begin{array}{l}\text { 10. I always tell myself that I am a } \\
\text { capable person. }\end{array}$ & 0.885 & & & & \\
\hline $\begin{array}{l}\text { 4. It is important to use } \\
\text { environmentally friendly products in } \\
\text { the workplace. }\end{array}$ & 0.782 & & & & & $\begin{array}{l}\text { 11. I have enough self-motivation to } \\
\text { continue. }\end{array}$ & 0.776 & & & & \\
\hline $\begin{array}{l}\text { 7. It is important to reduce harm to the } \\
\text { environment in the workplace. }\end{array}$ & 0.838 & & & & & $\begin{array}{l}\text { 12. I always tell myself that I should } \\
\text { try my best. }\end{array}$ & 0.818 & & & & \\
\hline
\end{tabular}


Table 1. Cont

\begin{tabular}{|c|c|c|c|c|c|c|c|c|c|c|c|}
\hline Constructs & Loadings & $\alpha$ & rho_A & CR & AVE & Constructs & Loadings & $\alpha$ & rho_A & CR & AVE \\
\hline SN & & 0.867 & 0.885 & 0.904 & 0.654 & $\begin{array}{l}\text { 13. I can manage my anger and deal } \\
\text { with problems rationally. }\end{array}$ & 0.712 & & & & \\
\hline $\begin{array}{l}\text { 1. People who are important to me } \\
\text { believe that I should reduce my use of } \\
\text { paper in the workplace. }\end{array}$ & 0.802 & & & & & $\begin{array}{l}\text { 14. I am fully capable of managing my } \\
\text { own emotions. }\end{array}$ & 0.870 & & & & \\
\hline $\begin{array}{l}\text { 2. People who are important to me } \\
\text { believe that I should conserve energy } \\
\text { in the workplace. }\end{array}$ & 0.752 & & & & & $\begin{array}{l}\text { 15. When I am angry, I can always cool } \\
\text { down quickly. }\end{array}$ & 0.774 & & & & \\
\hline $\begin{array}{l}\text { 3. People who are important to me } \\
\text { believe that I should reduce my plastic } \\
\text { waste in the workplace. }\end{array}$ & 0.803 & & & & & $\begin{array}{l}\text { 16. I have good control of my own } \\
\text { emotions. }\end{array}$ & 0.833 & & & & \\
\hline $\begin{array}{l}\text { 4. People who are important to me } \\
\text { think I should buy environmentally } \\
\text { friendly products in the workplace. }\end{array}$ & 0.836 & & & & & PEB & & 0.925 & 0.932 & 0.940 & 0.690 \\
\hline $\begin{array}{l}\text { 5. People who are important to me } \\
\text { think I should conserve resources in } \\
\text { the workplace. }\end{array}$ & 0.846 & & & & & $\begin{array}{l}\text { 1. Whenever possible, I print in } \\
\text { double-sided format at my office. }\end{array}$ & 0.835 & & & & \\
\hline 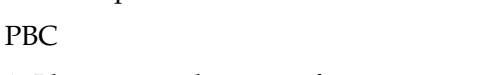 & & 0.881 & 0.896 & 0.918 & 0.737 & $\begin{array}{l}\text { 2. Every time I leave my office, I turn } \\
\text { off my computer or notepad. }\end{array}$ & 0.855 & & & & \\
\hline $\begin{array}{l}\text { 1. I have control over performing } \\
\text { pro-environment activities in the } \\
\text { workplace. }\end{array}$ & 0.820 & & & & & $\begin{array}{l}\text { 3. I switch off the lights when no one } \\
\text { else is at the office. }\end{array}$ & 0.879 & & & & \\
\hline $\begin{array}{l}\text { 2. I can perform environmental } \\
\text { pro-environment activities in the } \\
\text { workplace. }\end{array}$ & 0.888 & & & & & $\begin{array}{l}\text { 4. At work, I have my own cup that I } \\
\text { use for drinking. }\end{array}$ & 0.823 & & & & \\
\hline $\begin{array}{l}\text { 3. I have control over my actions to } \\
\text { support the environment in the } \\
\text { workplace. }\end{array}$ & 0.849 & & & & & $\begin{array}{l}\text { 5. At work, I try to avoid using plastic } \\
\text { bags. }\end{array}$ & 0.839 & & & & \\
\hline $\begin{array}{l}\text { 4. I have the ability to carry out } \\
\text { pro-environment activities in the } \\
\text { workplace. }\end{array}$ & 0.876 & & & & & $\begin{array}{l}\text { 6. I am reducing my water } \\
\text { consumption at work. }\end{array}$ & 0.832 & & & & \\
\hline 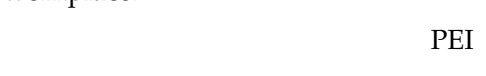 & & 0.804 & 0.834 & 0.873 & 0.634 & $\begin{array}{l}\text { 7. In my workplace, I engage in } \\
\text { environmentally friendly programs. }\end{array}$ & 0.745 & & & & \\
\hline
\end{tabular}

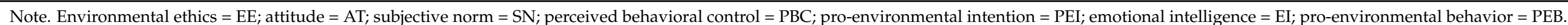




\section{Results}

\subsection{Profile of Respondents}

The demographic profile of the selected sample populations included work experience, gender, age, monthly salary, highest educational degree, and ethnicity. Among these respondents, $187(61.9 \%)$ were female and $115(38.1 \%)$ were male. The sample was spread out among all age groups: ages below $18-25$ years had one respondent $(0.3 \%)$, ages below 26-30 years had 24 respondents $(7.9 \%)$, ages below 31 to 40 years had 121 respondents $(40.1 \%)$, ages below 41 to 50 years had 124 respondents (41.1\%), and 32 respondents $(10.6 \%)$ were 50 years old and above. Regarding the qualification, the majority of the respondents held a Ph.D. degree (128 respondents; $42.4 \%), 61$ respondents $(20.2 \%)$ held a master's degree, 61 respondents $(20.2 \%)$ had a bachelor's degree, and 51 respondents $(16.9 \%)$ had a diploma degree.

Based on the respondents' experience levels, the majority of them had modest experience. A total of 87 respondents $(28.8 \%)$ had $1-5$ years of experience, followed by 86 respondents $(28.5 \%)$ who had 6-10 years of experience, 91 respondents $(30.1 \%)$ having $11-15$ years, and 38 respondents (12.6\%) having above 15 years of job experience. With regards to race, the respondents were Malay $(79.8 \%, \mathrm{n}=241)$, Chinese $(15.3 \%, \mathrm{n}=46)$, and Indian $(5 \%, \mathrm{n}=15)$.

\subsection{Measurement Model}

The measurement model was tested using exploratory factor analysis (EFA) and PLSSEM confirmatory factor analysis (CFA). To obtain the factor structure, all 54 items were subjected to EFA. In the initial stage of EFA, principal components analysis (PCA) with varimax rotation was employed. The Kaiser-Meyer-Olkin Measure of Sampling Adequacy $(\mathrm{KMO})$ value of 0.79 and the results of Bartlett's test of sphericity $(\chi 2=1755.95 ; p=0.000)$ indicated that the data were suitable for EFA. The number of factors was determined using the Kaiser criterion, with eigenvalues larger than one and only items with loadings greater than 0.60 retained. As a result, three items with factor loadings lower than 0.6 (PEI 5, ATT5, and ATT6) were eliminated. The seven factors with the remaining 51 items explained $66.9 \%$ of the total variance. The EFA results showed the corresponding eigenvalues for EI (7.78), EE (4.10), ATT (2.37), PEB (1.87), SN (1.61), EPEI (1.35), and PBC (1.05), while the corresponding portions of variance explained were $25.94,13.66,7.74,6.22,5.33,4.49$, and 3.49 , respectively.

PLS-SEM results suggested that the CFA model adequately fit the data (SRMR $=0.067$; NFI = 0.908; Hair et al. [81]). Significant correlations were found between the factors when the latent variable correlations were examined $(p<0.01)$. All factor loadings were above 0.70 and all extracted average variance (AVE) values were greater than 0.5 , indicating convergent validity (Table 1). Furthermore, all composite reliability (CR) values ranged between 0.873 and 0.953 , indicating internal consistency. Finally, the Dijkstra-Henseler Rho_A values for all constructs were higher than 0.7 [81] (Table 1).

The variance inflation factors (VIF) were used in this analysis to investigate multicollinearity. A VIF greater than 5 implies multicollinearity. The VIF values in this analysis were lower than the standard parameters, suggesting that there was no multicollinearity issue (see Table 2) [84].

Discriminant validity compares the degree of one construct to another using empirical standards. As proposed by researchers to combine several methods, this study applied the Fornell-Larcker criterion with the Heterotrait-Monotrait (HTMT) ratio of correlations [84]. Following the Fornell-Larcker criterion, the results indicated that the discriminant validity was achieved because the square root of the AVE of each construct was higher than the correlation values among any construct pairings. Furthermore, the HTMT values were below the threshold level of 0.85 in all cases, as shown in Table 3. Consequently, these results confirmed the discriminant validity of the study. 
Table 2. Multi-collinearity test for exogenous latent constructs.

\begin{tabular}{cccccc}
\hline Construct & $\mathbf{1}$ & $\mathbf{2}$ & $\mathbf{3}$ & $\mathbf{4}$ & $\mathbf{5}$ \\
\hline 1.ATT & & & & & \\
2.VPEB & & & & & \\
3.VPEI & 1.285 & 1.947 & & \\
4.EE & 1.000 & & 1.000 & \\
5.EI & & & 2.201 & 1.000 & \\
6.PBC & & & 1.752 & 1.000 & \\
7.SN & & &
\end{tabular}

Note. Environmental ethics $=\mathrm{EE}$; attitude $=\mathrm{AT}$; subjective norm $=\mathrm{SN}$; perceived behavioral control $=\mathrm{PBC}$; pro-environmental intention $=$ EPEI; emotional intelligence $=$ EI; pro-environmental behavior $=$ PEB .

Table 3. Measurement model: discriminant validity.

\begin{tabular}{|c|c|c|c|c|c|c|c|c|c|c|c|c|c|}
\hline \multirow[b]{2}{*}{ Construct } & \multicolumn{7}{|c|}{ Fornell-Larcker Criterion } & \multicolumn{6}{|c|}{ Heterotrait-Monotrait Ratio (HTMT) } \\
\hline & 1 & 2 & 3 & 4 & 5 & 6 & 9 & 1 & 2 & 3 & 4 & 5 & 6 \\
\hline 1. ATT & 0.799 & & & & & & & & & & & & \\
\hline 2. PEB & 0.380 & 0.831 & & & & & & 0.395 & & & & & \\
\hline 3. PEI & 0.454 & 0.379 & 0.796 & & & & & 0.539 & 0.429 & & & & \\
\hline 4. EE & 0.415 & 0.553 & 0.265 & 0.780 & & & & 0.423 & 0.595 & 0.298 & & & \\
\hline 5. EI & 0.472 & 0.365 & 0.602 & 0.293 & 0.848 & & & 0.539 & 0.397 & 0.716 & 0.318 & & \\
\hline 6. PBC & 0.438 & 0.243 & 0.480 & 0.269 & 0.492 & 0.859 & & 0.502 & 0.261 & 0.565 & 0.291 & 0.558 & \\
\hline 7. SN & 0.437 & 0.242 & 0.452 & 0.211 & 0.502 & 0.726 & 0.808 & 0.507 & 0.268 & 0.535 & 0.231 & 0.577 & 0.530 \\
\hline
\end{tabular}

Note. $\mathrm{ATT}=$ attitude; EI = emotional Intelligence; VPEB = pro-environmental behavior; $\mathrm{EE}=$ environmental ethic; $\mathrm{PBC}=$ perceived behavioral control; $\mathrm{SN}$ = subjective norm.

\subsection{Structural Model}

The $\mathrm{R}^{2}, \mathrm{Q}^{2}$, and significance of paths were used to evaluate the structural model. Table 4 displays that all $R^{2}$ values are greater than 0.1 . As a result, predictive capacity has been developed. The $\mathrm{Q}^{2}$ also confirms the endogenous constructs' predictive validity. A Q2 value greater than 0 indicates that the model is predictively relevant. The findings demonstrate that there is significance in the prediction of the constructs (see Table 3). In addition to that, the results displayed that the model fit the data, as the standardized root mean square residual value was 0.122 , which was significantly higher than the required value of 0.10 .

Table 4. Testing direct relationships.

\begin{tabular}{|c|c|c|c|c|c|}
\hline & Path Coefficient & $S D$ & $t$ Value (Bootstrap) & $p$ Values & BI $(2.5 \% ; 97.5 \%)$ \\
\hline $\mathrm{H} 1: \mathrm{EE} \rightarrow \mathrm{ATT}$ & 0.415 & 0.056 & 7.382 & 0.000 & {$[0.303 ; 0.528]$} \\
\hline $\mathrm{H} 2: \mathrm{EE} \rightarrow \mathrm{SN}$ & 0.211 & 0.066 & 3.169 & 0.002 & {$[0.085 ; 0.338]$} \\
\hline $\mathrm{H} 3: \mathrm{EE} \rightarrow \mathrm{PBC}$ & 0.269 & 0.063 & 4.265 & 0.000 & {$[0.147 ; 0.389]$} \\
\hline H4: ATT $\rightarrow$ PEI & 0.280 & 0.057 & 4.865 & 0.000 & {$[0.170 ; 0.397]$} \\
\hline $\mathrm{H} 5: \mathrm{SN} \rightarrow \mathrm{PEI}$ & 0.148 & 0.087 & 1.701 & 0.089 & {$[-0.014 ; 0.321]$} \\
\hline H6: PBC $\rightarrow$ PEI & 0.249 & 0.083 & 2.986 & 0.003 & {$[0.091 ; 0.408]$} \\
\hline $\mathrm{R}^{2} \mathrm{ATT}=0.172$ & $\mathrm{Q}^{2} \mathrm{ATT}=0.089$ & & & & \\
\hline $\mathrm{R}^{2} \mathrm{SN}=0.144$ & $\mathrm{Q}^{2} \mathrm{SN}=0.026$ & & & & \\
\hline $\mathrm{R}^{2} \mathrm{PBC}=0.172$ & $\mathrm{Q}^{2} \mathrm{PBC}=0.049$ & & & & \\
\hline $\mathrm{R}^{2} \mathrm{PEI}=0.314$ & $\mathrm{Q}^{2} \mathrm{PEI}=0.183$ & & & & \\
\hline $\mathrm{R}^{2} \mathrm{PEB}=0.191$ & $\widehat{\mathrm{Q}^{2}} \mathrm{PEB}=0.117$ & & & & \\
\hline
\end{tabular}

Note: BI, bias-corrected confidence interval; ATT, attitude; PBC, perceived behavioral control; SN, subjective norm; PEI, pro-environmental intention; $\mathrm{PEB}$, pro-environmental behavior.

To determine the significance (path coefficient) of relationships between the variables (see Table 4), the bootstrapping technique was utilized [81]. As shown in Table 4, EE significantly impacted ATT $(\beta=0.415, \mathrm{t}=7.382, p=0.000)$. Hence, $\mathrm{H}_{1}$ was supported. The 
results revealed that EE significantly impacted $\mathrm{SN}(\beta=0.211, \mathrm{t}=3.169, p<0.002)$ and $\mathrm{PBC}$ ( $\beta=0.269, \mathrm{t}=4.265, p<0.001)$, supporting $\mathrm{H}_{2}$ and $\mathrm{H}_{3}$. The findings showed a significant impact of ATT $(\beta=0.280, \mathrm{t}=4.865, p=0.000)$, insignificant impact of $\mathrm{SN}(\beta=0.148, \mathrm{t}=1.701$, $p=0.089)$, and significant impact of PBC $(\beta=0.249, \mathrm{t}=2.986, p=0.003)$ on PEI, supporting $\mathrm{H}_{4}$ and $\mathrm{H}_{6}$ and failing to support $\mathrm{H}_{5}$.

\subsection{Mediation Analysis}

To determine the mediating roles of PEI and EI, a mediation study was conducted. The results (see Table 5) showed partially significant mediating role of PEI in the relationship between ATT $\left(\mathrm{H}_{7}: \beta=0.106, \mathrm{t}=3.194, p=0.001\right)$ and $\mathrm{PBC}\left(\mathrm{H}_{9}: \beta=0.094, \mathrm{t}=2.736\right.$, $p=0.006$ ), and PEB. Besides that, the results (See Table 5) revealed that PEI did not mediate the relationships between $\mathrm{SN}$ and $\mathrm{PEB}\left(\mathrm{H}_{8}: \beta=0.056, \mathrm{t}=1.553, p=0.121\right)$. EI $\left(\mathrm{H}_{10}: \beta=0.212\right.$, $t=4.578, p=0.00$ ) fully mediated the relation between PEI and PEB. All results are exhibited in Figure 2.

Table 5. Mediation analysis.

\begin{tabular}{|c|c|c|c|c|c|c|c|c|c|c|}
\hline \multicolumn{3}{|c|}{ Total Effect } & \multicolumn{2}{|c|}{ Direct Effect } & \multirow[t]{2}{*}{ Indirect Effects } & \multirow[b]{2}{*}{ Coefficient } & \multirow[b]{2}{*}{$S D$} & \multirow[b]{2}{*}{$\begin{array}{c}t \text { Value } \\
\text { (Bootstrap) }\end{array}$} & \multirow[b]{2}{*}{$p$ Values } & \multirow[b]{2}{*}{$\begin{array}{c}\text { BI } \\
{[2.5 \% ; 97.5 \%]}\end{array}$} \\
\hline Paths & Coefficient & $p$ Value & Coefficient & $p$ Value & & & & & & \\
\hline ATT-PEB & 0.280 & 0.003 & 0.198 & 0.022 & $\mathrm{H} 7: \mathrm{ATT} \rightarrow \mathrm{PEI} \rightarrow \mathrm{PEB}$ & 0.106 & 0.033 & 3.194 & 0.001 & {$[0.052 ; 0.178]$} \\
\hline SN-PEB & 0.148 & 0.065 & 0.114 & 0.087 & H8: $\mathrm{SN} \rightarrow \mathrm{PEI} \rightarrow \mathrm{PEB}$ & 0.056 & 0.036 & 1.553 & 0.121 & {$[-0.006 ; 0.132]$} \\
\hline PBC-PEB & 0.249 & 0.006 & 0.178 & 0.016 & $\mathrm{H} 9: \mathrm{PBC} \rightarrow \mathrm{PEI} \rightarrow \mathrm{PEB}$ & 0.094 & 0.035 & 2.736 & 0.006 & {$[0.034 ; 0.165]$} \\
\hline PEI-PEB & 0.234 & 0.008 & 0.106 & 0.093 & $\mathrm{H} 10: \mathrm{PEI} \rightarrow \mathrm{EI} \rightarrow \mathrm{PEB}$ & 0.212 & 0.046 & 4.578 & 0.000 & {$[0.122 ; 0.305]$} \\
\hline
\end{tabular}

Note: BI, bias-corrected confidence interval; ATT, attitude; PBC, perceived behavioral control; SN, subjective norm; PEI, pro-environmental intention; PEB, pro-environmental behavior.

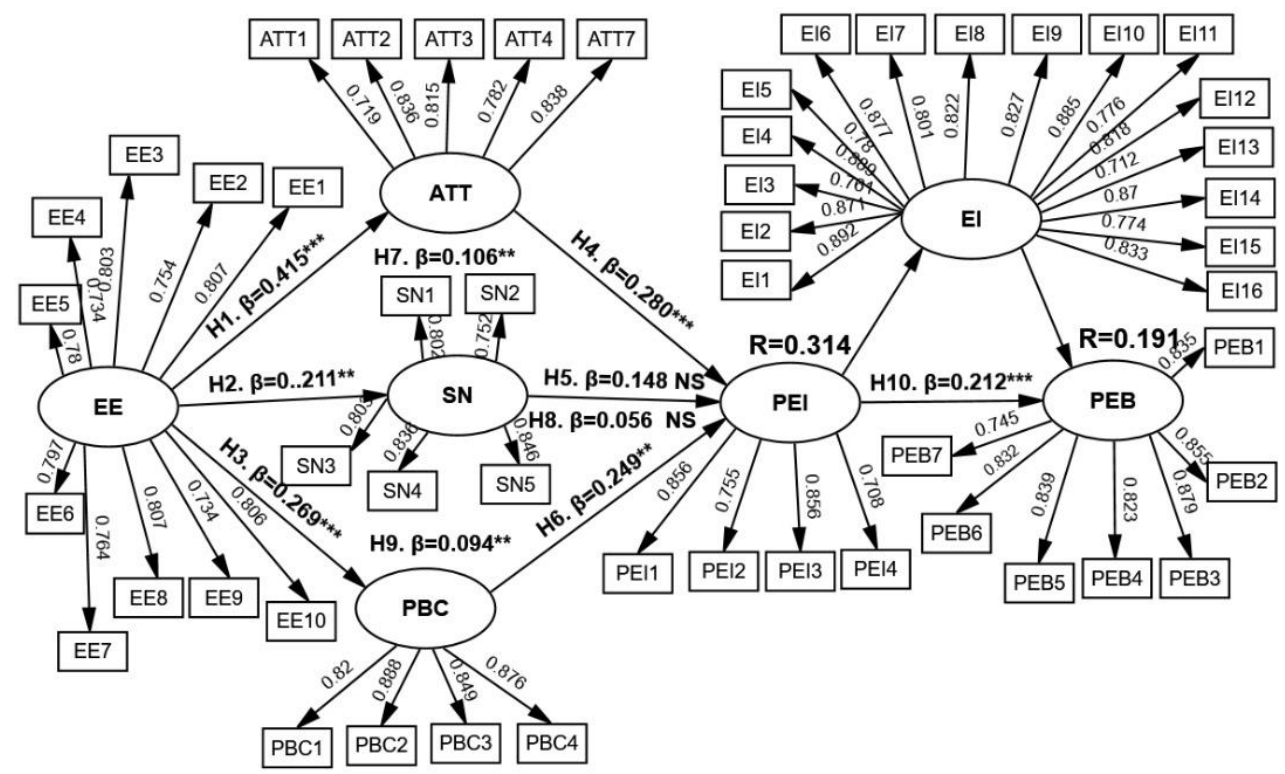

Figure 2. The results of structural model. Notes: ${ }^{* *} p<0.01 ;{ }^{* * *} p<0.001$; NS statistically non-significant; EE: environmental ethics; EI: emotional intelligence ATT: attitude; SN: subjective norm; PBC: perceived behavioral control; PEI: pro-environmental intention; PEB: pro-environmental behaviour.

\section{Discussion and Implications}

The aim of this study was to add the variables of EI and EE to TPB to examine the factors influencing the PEB of university employees in Malaysia. The study provides a deeper explanation of the relations between EE, ATT, SN, PBC, and EI and university employees' intentions towards PEB. The results of this study proved that EE significantly influenced ATT toward the PEB, which in turn became the most significant predictor of the PEBI of university employees. The findings are consistent with previous studies 
that indicate significant relations between value and ethics, ATT, and intention $[85,86]$. Another significant finding was that EE directly affected respondents' $\mathrm{PBC}$ and $\mathrm{SN}$, which have not been evaluated in the context of PEB in the workplace. As a result, university administrators must be aware of EE, rethink their ethical standards to employees, and assist them in the development of ethical decisions, since EE has been found to significantly impact ATT, $\mathrm{PBC}$, and SNs, affecting university employees' intention to participate in proenvironmental activities on campus. Besides that, unless universities punish employees for wasting resources, employees might use energy in an inefficient manner because they have no financial obligation to do so, whether or not they ethically believe in sustainability or follow pro-environmental values. Employees can further save energy and participate in any activities relevant to sustainability if their ethical behavior clearly forbids unsustainable behavior, and if their EE promises punishment for unsustainable behavior.

The findings also confirmed that university employees' ATT directly impacts their intention for PEB. This is in line with previous studies by Bauer et al. [87] and Yusliza et al. [88]. Anthony Swaim et al. [74] reported that employee personal attitude was critical to generate a desirable level of environmental sustainability intention. Hence, any organization needs to ensure that the attitude of their employees is in line with the company's objective in promoting organizational sustainability. This is because an employee who is in favor of certain behavior or action will put effort into acting. In the context of this study, the employee who is in favor of protecting the environment in their workplace will make an effort to conserve, work sustainably, and avoid harm when preserving the environment in the workplace.

However, some other studies $[7,30,74,89]$ demonstrated that SNs did not significantly and directly affect PEBI among university employees in Malaysia. According to the result of this study, the assumption of social pressure from others for the employee to behave in a certain manner and their motivation to comply with those people's views to perform a certain behavior or action will not lead to their effort of acting. Mei et al. [90] believe that this situation is due to the declining trend of the Environmental Performance Index Ranking of Malaysia from 51 in the year 2014 to 75 in the year 2018, showing that Malaysia was still lacking a comprehensive method to present the environmental awareness and behavior performance of Malaysians. Since Malaysian environmental awareness and behavior did not positively correlate [90], the universities' employees who were surrounded by others (superiors, subordinates, and colleagues) who were not acting to protect the environment would influence the former to not to make an effort to conserve, work sustainably, and avoid harm when preserving the environment in the workplace.

Apart from that, PBC directly impacted PEBI. This result is consistent with a previous study [73] that suggests that the increased levels of PBC lead to increased PEBI. Consequently, the employees' belief in personal control to perform a specific behavior or action will influence their effort to proceed with that action. According to the findings of this study, as employees increase their finances and morale, such as obtaining enough money to purchase renewable goods and being able to minimize paper, energy, and plastic use, they increase their commitment to environmental conservation, increasing their desire to preserve the environment. As a consequence, university administration must plan and implement sustainability initiatives to strengthen employees' ATT and personal norms, as well as eliminate potential obstacles to ensure pro-environmental lifestyles. Furthermore, the findings of this study also confirmed the mediating role of PEBI, which significantly and positively affected the relationship between ATT and PBC. This result is consistent with other studies $[30,40,74]$. Therefore, the intention of an employee to perform a specific behavior is stronger when the degree of ATT and perceived ease towards PEB are high. Lastly, this study addressed the numerous constraints and limitations that left room for conceptual and operational improvement in TPB [91]. Existing studies [92,93] revealed that strong intention did not sufficiently lead towards a given behavior, suggesting that adding more constructs would increase the predictability between intention and behavior in TPB constructs [94,95]. Parallel to this, this study emphasized the significant contribution of 
EI as the mediator between PEBI and PEB. This result is in line with the previous studies $[14,96]$ that suggested that decision-making models such as the TPB should subsume emotions and take greater consideration of the factors that facilitated the intentions.

The employees with elevated levels of EI had more rewarding interpersonal interactions with their coworkers and exhibited more prosocial attitudes and behavior. In other words, the employee can use their intellect and emotional control to assess those environmental issues and decide how to respond to them. As a result, a university employee with a high environmental awareness will use their EI to make environmental protection more desirable, continue with their intention to protect the environment, and contribute to PEB in the workplace. By these particular assumptions, the researcher believes that the anticipated function of EI will contribute to PEB literature by examining other associated variables or antecedents that may reinforce the relationship within the TPB model's constructs. Thus, the university's administration would rely on increasing the EI of their employees to meet their environmental sustainability initiatives. This can be accomplished by training, motivational activities, and management-employee engagement. In the future, the management will consider recruiting an employee with a high level of EI so that they can use their ability to regulate their emotions to provide a positive feeling in protecting the environment in their workplace.

\section{Conclusions}

In conclusion, the study demonstrated that the extended TPB model was effective to study the predictors of the PEB of university employees. According to the findings, EI and EE increase the predictive validity of the TPB model on PEB. The two constructs included in the model also help to clarify their interrelationships, which were critical for advancing the TPB paradigm in the PEI domain. The introduction of the EE and EI constructs allows this to be the first known study that extends the application of TPB for predicting the PEB of university employees in the Malaysian context. Furthermore, the results point to three outcomes. Firstly, the results contributed to the pro-environmental literature by providing additional empirical support for EE in predicting the three constructs of TPB (i.e., ATT, SN, and $\mathrm{PBC}$ ), along with the significant effects of ATT and PBC in predicting PEI. Secondly, contrary to the results of direct effect, the results display a partially significant mediating role of EI in the relationship between ATT, PBC, and PEB. Thirdly, this study uncovered that EI mediated the effects of PEI on PEB. Overall, the findings offer important insights for policy-makers and university managers in developing countries such as Malaysia, which can assist in better understanding university employees' PEB and further emphasize the vital role of this context in the TPB.

\section{Limitations and Future Research Directions}

There were certain limitations to the study, which could be addressed in future research endeavors. Initially, the main variables were assessed using self-report, and part of the covariance between predictor and outcome variables could be attributed to common method variance. As a result, one effective approach is to perform longitudinal research that can demonstrate the causality of the relationships examined in this research. Next, the study did not take into account how much time the university had invested, which was critical in the long-term improvements of employee behavior. As a result, researchers may undertake additional researches to investigate the connection between university sustainability policies and activities and behavioral improvements in university staff toward an equitable and sustainable society.

A further significant limitation is that this research was limited to only one nation, Malaysia. Physical, legislative, and cultural differences can restrict or enhance the organization's efforts to establish environmental policies and achieve sustainability-related objectives. Furthermore, these cultural contexts can influence how university staff interpret and identify university policies and human resource management (HRM) practices. While this study framed TPB constructs, it also included variables such as ethics to foster PEB in 
university employees. The authors did not expand the study to determine whether there was an association between particular HRM practices and the degree to which university staff were inclined to participate in PEB. As a result, future studies should determine if there is a connection between individual HRM activities and the degree to which university staff participate in PEB. Future studies should look into this relationship because it will help universities choose where to focus their efforts to maximize their positive impacts on the environment.

Author Contributions: Conceptualization, F.A. and Z.Z.; methodology, F.A.; software, Z.Z.; validation, A.A.M.R., F.A., and Z.Z.; formal analysis, F.A.; investigation, S.A.; resources, F.A.; data curation, Z.Z.; writing-original draft preparation, Z.Z.; writing-review and editing, F.A. and Z.Z.; visualization, S.A. and A.A.M.R.; supervision, F.A.; project administration, F.A. All authors have read and agreed to the published version of the manuscript.

Funding: This research received no external funding.

Institutional Review Board Statement: Not applicable.

Informed Consent Statement: Informed consent was obtained from all subjects involved in the study.

Data Availability Statement: Not applicable.

Conflicts of Interest: The authors declare no conflict of interest.

\section{References}

1. Ciocirlan, C.E. Environmental workplace behaviors: Definition matters. Organ. Environ. 2017, 30, 51-70. [CrossRef]

2. Das, A.K.; Biswas, S.R.; Abdul Kader Jilani, M.M.; Uddin, M. Corporate environmental strategy and voluntary environmental behavior-Mediating effect of psychological green climate. Sustainability 2019, 11, 3123. [CrossRef]

3. Alzaidi, S.M.; Iyanna, S. Developing a conceptual model for voluntary pro-environmental behavior of employees. Soc. Responsib. J. 2021. ahead-of-print. [CrossRef]

4. Büchs, M.; Edwards, R.; Smith, G. Third Sector Organisations' Role in Pro-Environmental Behaviour Change-A Review of the Literature and Evidence; Third Sector Research Centre: Birmingham, UK, 2012; pp. 1-19.

5. Steward, F.; Liff, S.; Dunkelman, M. Mapping the Big Green Challenge: An Analysis of 355 Community Proposals for Low Carbon Innovation; Appleby Ltd.: Swadlincote, UK, 2009.

6. Cooper, C.; Larson, L.; Dayer, A.; Stedman, R.; Decker, D. Are wildlife recreationists conservationists? Linking hunting, birdwatching, and pro-environmental behavior. J. Wildl. Manag. 2015, 79, 446-457. [CrossRef]

7. Ajzen, I. The theory of planned behavior. Organ. Behav. Hum. Decis. Process. 1991, 50, 179-211. [CrossRef]

8. Fielding, K.S.; McDonald, R.; Louis, W.R. Theory of planned behaviour, identity and intentions to engage in environmental activism. J. Environ. Psychol. 2008, 28, 318-326. [CrossRef]

9. Maki, A.; Rothman, A.J. Understanding proenvironmental intentions and behaviors: The importance of considering both the behavior setting and the type of behavior. J. Soc. Psychol. 2017, 157, 517-531. [CrossRef]

10. Stets, J.E.; Biga, C.F. Bringing identity theory into environmental sociology. Sociol. Theory 2003, 21, 398-423. [CrossRef]

11. Han, H.; Ryu, K. The theory of repurchase decision-making (TRD): Identifying the critical factors in the post-purchase decisionmaking process. Int. J. Hosp. Manag. 2012, 31, 786-797. [CrossRef]

12. Harth, N.S.; Leach, C.W.; Kessler, T. Guilt, anger, and pride about in-group environmental behaviour: Different emotions predict distinct intentions. J. Environ. Psychol. 2013, 34, 18-26. [CrossRef]

13. Chowdhury, R.M. Emotional intelligence and consumer ethics: The mediating role of personal moral philosophies. J. Bus. Ethics 2017, 142, 527-548. [CrossRef]

14. Kim, Y.J.; Njite, D.; Hancer, M. Anticipated emotion in consumers' intentions to select eco-friendly restaurants: Augmenting the theory of planned behavior. Int. J. Hosp. Manag. 2013, 34, 255-262. [CrossRef]

15. Kaiser, F.G.; Ranney, M.; Hartig, T.; Bowler, P.A. Ecological behavior, environmental attitude, and feelings of responsibility for the environment. Eur. Psychol. 1999, 4, 59-74. [CrossRef]

16. Arvola, A.; Vassallo, M.; Dean, M.; Lampila, P.; Saba, A.; Lähteenmäki, L.; Shepherd, R. Predicting intentions to purchase organic food: The role of affective and moral attitudes in the Theory of Planned Behaviour. Appetite 2008, 50, 443-454. [CrossRef] [PubMed]

17. Taylor, S.; Todd, P. Decomposition and crossover effects in the theory of planned behavior: A study of consumer adoption intentions. Int. J. Res. Mark. 1995, 12, 137-155. [CrossRef]

18. Cheung, S.F.; Chan, D.K.-S.; Wong, Z.S.-Y. Reexamining the Theory of Planned Behavior in Understanding Wastepaper Recycling. Environ. Behav. 1999, 31, 587-612. [CrossRef]

19. Ajzen, I.; Fishbein, M. Understanding Attitudes and Predicting Social Behavior; Prentice-Hall: Englewood-Cliffs, NJ, USA, 1980. 
20. Botetzagias, I.; Malesios, C.; Poulou, D. Electricity curtailment behaviors in Greek households: Different behaviors, different predictors. Energy Policy 2014, 69, 415-424. [CrossRef]

21. Muñoz, B.; Monzon, A.; López, E. Transition to a cyclable city: Latent variables affecting bicycle commuting. Transp. Res. Part A Policy Pract. 2016, 84, 4-17. [CrossRef]

22. Russell, S.V.; Young, C.W.; Unsworth, K.L.; Robinson, C. Bringing habits and emotions into food waste behaviour. Resour. Conserv. Recycl. 2017, 125, 107-114. [CrossRef]

23. Botetzagias, I.; Dima, A.-F.; Malesios, C. Extending the theory of planned behavior in the context of recycling: The role of moral norms and of demographic predictors. Resour. Conserv. Recycl. 2015, 95, 58-67. [CrossRef]

24. Lizin, S.; Van Dael, M.; Van Passel, S. Battery pack recycling: Behaviour change interventions derived from an integrative theory of planned behaviour study. Resour. Conserv. Recycl. 2017, 122, 66-82. [CrossRef]

25. Mancha, R.M.; Yoder, C.Y. Cultural antecedents of green behavioral intent: An environmental theory of planned behavior. J. Environ. Psychol. 2015, 43, 145-154. [CrossRef]

26. Visschers, V.H.; Wickli, N.; Siegrist, M. Sorting out food waste behaviour: A survey on the motivators and barriers of self-reported amounts of food waste in households. J. Environ. Psychol. 2016, 45, 66-78. [CrossRef]

27. Shi, H.; Wang, S.; Zhao, D. Exploring urban resident's vehicular PM2. 5 reduction behavior intention: An application of the extended theory of planned behavior. J. Clean. Prod. 2017, 147, 603-613. [CrossRef]

28. Echegaray, F.; Hansstein, F.V. Assessing the intention-behavior gap in electronic waste recycling: The case of Brazil. J. Clean. Prod. 2017, 142, 180-190. [CrossRef]

29. Dixon, G.N.; Deline, M.B.; McComas, K.; Chambliss, L.; Hoffmann, M. Saving energy at the workplace: The salience of behavioral antecedents and sense of community. Energy Res. Soc. Sci. 2015, 6, 121-127. [CrossRef]

30. Blok, V.; Wesselink, R.; Studynka, O.; Kemp, R. Encouraging sustainability in the workplace: A survey on the pro-environmental behaviour of university employees. J. Clean. Prod. 2015, 106, 55-67. [CrossRef]

31. Chen, H.-J.; Chen, P.-J.; Okumus, F. The relationship between travel constraints and destination image: A case study of Brunei. Tour. Manag. 2013, 35, 198-208. [CrossRef]

32. Chew, E.Y.T.; Jahari, S.A. Destination image as a mediator between perceived risks and revisit intention: A case of post-disaster Japan. Tour. Manag. 2014, 40, 382-393. [CrossRef]

33. Petrides, K.V.; Sangareau, Y.; Furnham, A.; Frederickson, N. Trait emotional intelligence and children's peer relations at school. Soc. Dev. 2006, 15, 537-547. [CrossRef]

34. Schokman, C.; Downey, L.A.; Lomas, J.; Wellham, D.; Wheaton, A.; Simmons, N.; Stough, C. Emotional intelligence, victimisation, bullying behaviours and attitudes. Learn. Individ. Differ. 2014, 36, 194-200. [CrossRef]

35. Salovey, P.; Mayer, J.D. Emotional intelligence. Imagin. Cogn. Personal. 1990, 9, 185-211. [CrossRef]

36. Mayer, J.D.; Salovey, P. What is emotional intelligence. Emot. Dev. Emot. Intell. Educ. Implic. 1997, 3, 31.

37. Diessner, R.; Genthôs, R.; Praest, K.; Pohling, R. Identifying with nature mediates the influence of valuing nature's beauty on proenvironmental behaviors. Ecopsychology 2018, 10, 97-105. [CrossRef]

38. Landa, J.M.A.; López-Zafra, E.; Martos, M.P.B.; del Carmen Aguilar-Luzon, M. The relationship between emotional intelligence, occupational stress and health in nurses: A questionnaire survey. Int. J. Nurs. Stud. 2008, 45, 888-901. [CrossRef]

39. Izzi Dien, M. The Envizronmental Dimensions of Islam; The Lutterworth Press: Cambridge, MA, USA, 2000.

40. Bamberg, S.; Möser, G. Twenty years after Hines, Hungerford, and Tomera: A new meta-analysis of psycho-social determinants of pro-environmental behaviour. J. Environ. Psychol. 2007, 27, 14-25. [CrossRef]

41. Treviño, L.K.; Butterfield, K.D.; McCabe, D.L. The ethical context in organizations: Influences on employee attitudes and behaviors. In The Next Phase of Business Ethics: Integrating Psychology and Ethics; Dienhart, J., Moberg, D., Duska, R., Eds.; Emerald Group Publishing Limited: Bingley, UK, 2001; pp. 301-337.

42. Abedi Sarvestani, A. Explaining the Theory of Bio-Environmental Ethics of Students and Professors of Shiraz University with the Theory of Procedures. Ph.D. Thesis, Shiraz University, Shiraz, Iran, 2008.

43. Kibert, C.J.; Thiele, L.; Peterson, A.; Monroe, M. The Ethics of Sustainability. In Theory and in Fact. In Reshaping the built Environment; Kibert, C.J., Ed.; Island Press: Washington, DC, USA, 2010.

44. Abedi Sarvestani, A.; Shah Vali, M. Necessity and Features of Conducting Research on Environmental Education. J. Ethics Sci. Technol. 2008, 3, 56-61.

45. Thøgersen, J.; Ölander, F. Human values and the emergence of a sustainable consumption pattern: A panel study. J. Econ. Psychol. 2002, 23, 605-630. [CrossRef]

46. Honkanen, P.; Verplanken, B.; Olsen, S.O. Ethical values and motives driving organic food choice. J. Consum. Behav. Int. Res. Rev. 2006, 5, 420-430. [CrossRef]

47. Harland, P.; Staats, H.; Wilke, H.A. Explaining proenvironmental intention and behavior by personal norms and the Theory of Planned Behavior. J. Appl. Soc. Psychol. 1999, 29, 2505-2528. [CrossRef]

48. Yoon, C. Ethical decision-making in the Internet context: Development and test of an initial model based on moral philosophy. Comput. Hum. Behav. 2011, 27, 2401-2409. [CrossRef]

49. Conner, M.; Armitage, C.J. Extending the theory of planned behavior: A review and avenues for further research. J. Appl. Soc. Psychol. 1998, 28, 1429-1464. [CrossRef] 
50. Chang, S.-H.; Chou, C.-H. Consumer intention toward bringing Your Own shopping bags in Taiwan: An application of ethics perspective and theory of planned behavior. Sustainability 2018, 10, 1815. [CrossRef]

51. Dowd, K.; Burke, K.J. The influence of ethical values and food choice motivations on intentions to purchase sustainably sourced foods. Appetite 2013, 69, 137-144. [CrossRef]

52. Yousef, D.A. Organizational commitment, job satisfaction and attitudes toward organizational change: A study in the local government. Int. J. Public Adm. 2017, 40, 77-88. [CrossRef]

53. Soleimani, N.; Tebyanian, E. A Study of the Relationship between Principals' Creativity and Degree of Environmental Happiness in Semnan High Schools. In Proceedings of the International Conference on Education and Educational Psychology (ICEEPSY 2011), Istanbul, Turkey, 19-22 October 2011; 2.

54. Caciuc, V.-T. The role of virtue ethics in training students' environmental attitudes. Procedia-Soc. Behav. Sci. 2013, 92, 122-127. [CrossRef]

55. Manning, R.; Valliere, W.; Minteer, B. Values, ethics, and attitudes toward national forest management: An empirical study. Soc. Nat. Resour. 1999, 12, 421-436.

56. Sun, W. Toward a Theory of Ethical Consumer Intention Formation: Re-Extending the Theory of Planned Behavior. AMS Rev. 2019, 10, 1-19. [CrossRef]

57. Schwartz, A.J. Rate, relative risk, and method of suicide by students at 4-year colleges and universities in the United States, 2004-2005 through 2008-2009. Suicide Life Threat. Behav. 2011, 41, 353-371. [CrossRef]

58. Guido, G.; Prete, M.I.; Peluso, A.M.; Maloumby-Baka, R.C.; Buffa, C. The role of ethics and product personality in the intention to purchase organic food products: A structural equation modeling approach. Int. Rev. Econ. 2010, 57, 79-102. [CrossRef]

59. Park, J.; Ha, S. Understanding consumer recycling behavior: Combining the theory of planned behavior and the norm activation model. Fam. Consum. Sci. Res. J. 2014, 42, 278-291. [CrossRef]

60. Masud, M.M.; Al-Amin, A.Q.; Junsheng, H.; Ahmed, F.; Yahaya, S.R.; Akhtar, R.; Banna, H. Climate change issue and theory of planned behaviour: Relationship by empirical evidence. J. Clean. Prod. 2016, 113, 613-623. [CrossRef]

61. Ateş, H. Merging theory of planned behavior and value identity personal norm model to explain pro-environmental behaviors. Sustain. Prod. Consum. 2020, 24, 169-180. [CrossRef]

62. Taufique, K.M.R.; Vaithianathan, S. A fresh look at understanding Green consumer behavior among young urban Indian consumers through the lens of Theory of Planned Behavior. J. Clean. Prod. 2018, 183, 46-55. [CrossRef]

63. Ajzen, I. The theory of planned behaviour: Reactions and reflections. Psychol. Health 2011, 26, 1113-1127. [CrossRef] [PubMed]

64. Lin, S.-C.; Nadlifatin, R.; Amna, A.R.; Persada, S.F.; Razif, M. Investigating citizen behavior intention on mandatory and voluntary pro-environmental programs through a pro-environmental planned behavior model. Sustainability 2017, 9, 1289. [CrossRef]

65. Effendi, M.I.; Sugandini, D.; Sukarno, A.; Kundarto, M.; Arundati, R. The Theory of Planned Behavior and Pro-Environmental Behavior among Students. J. Environ. Manag. Tour. 2020, 11, 35-43.

66. Mufidah, A.C. Hubungan Antara Dukungan Sosial Dengan Resiliensi Yang Dimoderatori Oleh Locus of Control Pada Mahasiswa Bidikmisi [Relationship between Social Support and Resilience with Locus of Control as Mediator in Students with Bidikmisi]. Psikodimensia 2018, 16, 30-121. [CrossRef]

67. Robinson, A.C.; Downey, L.A.; Ford, T.C.; Lomas, J.E.; Stough, C. Green teens: Investigating the role of emotional intelligence in adolescent environmentalism. Personal. Individ. Differ. 2019, 138, 225-230. [CrossRef]

68. Aguilar-Luzón, M.C.; Calvo-Salguero, A.; Salinas, J.M. Beliefs and environmental behavior: The moderating effect of emotional intelligence. Scand. J. Psychol. 2014, 55, 619-629. [CrossRef]

69. Robina-Ramírez, R.; Merodio, J.A.M.; McCallum, S. What role do emotions play in transforming students' environmental behaviour at school? J. Clean. Prod. 2020, 258, 120638. [CrossRef]

70. Chiang, Y.-C.; Li, D.; Jane, H.-A. Wild or tended nature? The effects of landscape location and vegetation density on physiological and psychological responses. Landsc. Urban Plan. 2017, 167, 72-83. [CrossRef]

71. Di Fabio, A.; Palazzeschi, L.; Bucci, O.; Guazzini, A.; Burgassi, C.; Pesce, E. Personality traits and positive resources of workers for sustainable development: Is emotional intelligence a mediator for optimism and hope? Sustainability 2018, 10, 3422. [CrossRef]

72. Guil, R.; Gómez-Molinero, R.; Merchan-Clavellino, A.; Gil-Olarte, P.; Zayas, A. Facing anxiety, growing up. Trait emotional intelligence as a mediator of the relationship between self-esteem and university anxiety. Front. Psychol. 2019, 10, 1-12. [CrossRef] [PubMed]

73. Fatoki, O. Hotel employees' pro-environmental behaviour: Effect of leadership behaviour, institutional support and workplace spirituality. Sustainability 2019, 11, 4135. [CrossRef]

74. Swaim, J.A.; Maloni, M.J.; Henley, A.; Campbell, S. Motivational influences on supply manager environmental sustainability behavior. Supply Chain Manag. Int. J. 2016, 21, 305-320. [CrossRef]

75. Han, H. Travelers' pro-environmental behavior in a green lodging context: Converging value-belief-norm theory and the theory of planned behavior. Tour. Manag. 2015, 47, 164-177. [CrossRef]

76. Sparks, B.; Pan, G.W. Chinese outbound tourists: Understanding their attitudes, constraints and use of information sources. Tour. Manag. 2009, 30, 483-494. [CrossRef]

77. Henriques, I.; Sadorsky, P. The relationship between environmental commitment and managerial perceptions of stakeholder importance. Acad. Manage. J. 1999, 42, 87-99. 
78. Singh, S.K.; Chen, J.; Giudice, M.D.; El-Kassar, A.-N. Environmental ethics, environmental performance, and competitive advantage: Role of environmental training. Technol. Forecast. Soc. Chang. 2019, 146, 203-211. [CrossRef]

79. Lundmark, C. The new ecological paradigm revisited: Anchoring the NEP scale in environmental ethics. Environ. Educ. Res. 2007, 13, 329-347. [CrossRef]

80. Wong, C.-S.; Law, K.S. The effects of leader and follower emotional intelligence on performance and attitude: An exploratory study. Leadersh. Q. 2002, 13, 243-274. [CrossRef]

81. Dagiliūtè, R.; Liobikienè, G. University contributions to environmental sustainability: Challenges and opportunities from the Lithuanian case. J. Clean. Prod. 2015, 108, 891-899. [CrossRef]

82. León-Fernández, Y.; Gomera, A.; Antúnez, M.; Martínez-Escrich, B.; Villamandos, F.; Vaquero, M. Enhancing environmental management in universities through participation: The case of the University of Córdoba. J. Clean. Prod. 2018, 172, $4328-4337$. [CrossRef]

83. Hair, J.F.; Hult, G.T.M.; Ringle, C.M.; Sarstedt, M. A Primer on Partial Least Squares Structural Equation Modeling (PLS-SEM), 2nd ed.; Sage: Singapore, 2017.

84. Tabachnick, B.G.; Fidell, L.S. Using Multivariate Statistics; International Edition; Pearson: Northridge, CA, USA, 2013.

85. Verma, V.K.; Chandra, B.; Kumar, S. Values and ascribed responsibility to predict consumers' attitude and concern towards green hotel visit intention. J. Bus. Res. 2019, 96, 206-216. [CrossRef]

86. Zaremohzzabieh, Z.; Ismail, N.; Ahrari, S.; Samah, A.A. The effects of consumer attitude on green purchase intention: A meta-analytic path analysis. J. Bus. Res. 2021, 132, 732-743. [CrossRef]

87. Bauer, T.N.; Erdogan, B.; Taylor, S. Creating and Maintaining Environmentally Sustainable Organizations: Recruitment and Onboarding. Bus. Fac. Publ. Present. 2012, 28, 1-27.

88. Yusliza, M.Y.; Amirudin, A.; Rahadi, R.A.; Athirah, N.A.N.S.; Ramayah, T.; Muhammad, Z.; Mas, F.D.; Massaro, M.; Saputra, J.; Mokhlis, S. An Investigation of Pro-Environmental Behaviour and Sustainable Development in Malaysia. Sustainability 2020, 12, 7083. [CrossRef]

89. Oztekin, C.; Teksöz, G.; Pamuk, S.; Sahin, E.; Kilic, D.S. Gender perspective on the factors predicting recycling behavior: Implications from the theory of planned behavior. Waste Manag. 2017, 62, 290-302. [CrossRef] [PubMed]

90. Mei, N.S.; Wai, C.W.; Ahamad, R. Environmental Awareness and Behaviour Index for Malaysia. Procedia-Soc. Behav. Sci. 2016, 222, 668-675. [CrossRef]

91. Londono, J.C.; Davies, K.; Elms, J. Extending the Theory of Planned Behavior to examine the role of anticipated negative emotions on channel intention: The case of an embarrassing product. J. Retail. Consum. Serv. 2017, 36, 8-20. [CrossRef]

92. Pakpour, A.H.; Zeidi, I.M.; Emamjomeh, M.M.; Asefzadeh, S.; Pearson, H. Household waste behaviours among a community sample in Iran: An application of the theory of planned behaviour. Waste Manag. 2014, 34, 980-986. [CrossRef] [PubMed]

93. Sheeran, P. Intention-behavior relations: A conceptual and empirical review. Eur. Rev. Soc. Psychol. 2002, 12, 1-36. [CrossRef]

94. Ajzen, I. Values, Attitudes, and Behavior. In Methods, Theories, and Empirical Applications in the Social Sciences; Salzborn, S., Reinecke, D.E., Eds.; Verlag für Sozialwissenschaften: Wiesbaden, Germany, 2012; pp. 33-38.

95. Herath, C.S. Eliciting Salient Beliefs are Critical to Predict Behavioural Change in Theory of Planned Behaviour. E-Psychology 2010, 4, 24-36.

96. Mohiyeddini, C.; Pauli, R.; Bauer, S. The role of emotion in bridging the intention-behaviour gap: The case of sports participation. Psychol. Sport Exerc. 2009, 10, 226-234. [CrossRef] 